\title{
Current advances in combining stem cell and gene therapy for neurodegenerative diseases
}

\author{
Ji-Yoon Hwang ${ }^{1,2,3,3^{*}}$, Jeong-Seob Won ${ }^{2,3,4,}$, Hyun Nam ${ }^{2,3,5}$, Hye Won Lee ${ }^{1,3}$, \\ Kyeung Min Joo ${ }^{1,2,3,4}$
}

\author{
${ }^{1}$ Department of Anatomy and Cell Biology, Sungkyunkwan University School of Medicine, Suwon, Korea \\ ${ }^{2}$ Stem Cell and Regenerative Medicine Center, Research Institute for Future Medicine, Samsung Medical Center, Seoul, Korea \\ ${ }^{3}$ Single Cell Network Research Center, Sungkyunkwan University School of Medicine, Suwon, Korea \\ ${ }^{4}$ Department of Health Sciences and Technology, SAIHST, Sungkyunkwan University, Seoul, Korea \\ ${ }^{5}$ Department of Neurosurgery, Samsung Medical Center, Sungkyunkwan University School of Medicine, Seoul, Korea
}

Received: April 2, 2018

Revised: June 18, 2018

Accepted: June 21, 2018

Corresponding authors:

Kyeung Min Joo

Department of Anatomy and

Cell Biology, Sungkyunkwan

University School of Medicine,

2066 Seobu-ro, Jangan-gu,

Suwon 16419, Korea

Tel: +82-31-299-6073

E-mail:kmjoo@skku.edu

Hye Won Lee

Department of Anatomy and

Cell Biology, Sungkyunkwan

University School of Medicine,

2066 Seobu-ro, Jangan-gu,

Suwon 16419, Korea

Tel: +82-31-299-6076

E-mail:nsproper@naver.com

*Ji-Yoon Hwang and Jeong-Seob Won contributed equally to this study as first authors.

This is an Open Access article distributed under the terms of the Creative Commons Attribution Non-Commercial License (http:// creativecommons.org/licenses/ by-nc/4.0/)

\section{ABSTRACT}

Neuronal death is the common final pathologic pathway of various neurodegenerative diseases (NDs). Although central nervous system has little regenerative potential, it is expected that damaged neural tissue can be recovered by exogenous supplementation of stem cells; however, stem cell therapy cannot modulate specific causes of NDs, such as accumulation of extracellular amyloid peptides in Alzheimer's disease. In contrast, gene therapy can deliver therapeutic genes to specific ND targets. Therefore, combining stem cell and gene therapy would have dual treatment mechanisms (regenerating damaged neural tissue and modifying specific causes of NDs) and lead to better clinical outcomes. In this review, we discuss various therapeutic genes that can be used to develop stem cell gene therapy for various NDs and the techniques for how therapeutic genes can be integrated into stem cells.

Keywords: Genetic therapy; Neurodegenerative diseases; Stem cells

\section{INTRODUCTION}

Neurodegenerative diseases (NDs) are various incurable conditions in the central nervous system (CNS). Despite the different locations and symptoms of NDs, their common final pathological pathway is neuronal dysfunction and loss [1]. The human CNS has poor ability to repair damage because neurons cannot spontaneously regenerate from residual nervous tissues [2]. NDs result in permanent and progressive losses of various CNS functions such as cognition, memory, and/or motor functions. Accordingly, there are few effective regenerative treatments for NDs; the current focus is only on delaying their progress [3].

Stem cells have self-renewal and multi-lineage differentiation capacities [4]. Based on their abilities, they come into the spotlight as novel candidates for regenerative treatment of NDs. 
Various types of stem cells have been established from human organs including nervous system tissues and have shown significant treatment efficacy in animal models of NDs $[5,6]$, and mesenchymal stem cells (MSCs) are the most advanced stem cell treatments for NDs [7]. However, recently neural stem cells (NSCs) have been identified from mammalian CNS and have been applied in preclinical and clinical ND trials [8]. NSCs are more promising than MSCs because of their spontaneous differentiation into neural cells [9]. However, stem cell therapies alone are still expected to have limited therapeutic effects in NDs because they cannot reverse specific ND processes. Therefore, disease-modifying abilities need to be added to the regenerative potential of stem cells to improve their treatment effects.

Gene therapy is a technique that uses therapeutic genes to treat or prevent diseases $[10,11]$. It is designed to introduce genetic materials into cells to modify genetic abnormality or to express beneficial proteins [12]. The combination of stem cell and gene therapy could be a technical breakthrough that increases the therapeutic efficacy of stem cells [13]. Therapeutic genes that can modify the specific deteriorated molecular pathways of NDs might give stem cell therapies regenerative and treatment functions simultaneously. Based on this concept, we focus in this review on candidate therapeutic genes that can be delivered to stem cell treatments and on methods of gene delivery.

\section{THERAPEUTIC TARGETS AND CANDIDATE GENES FOR NDS}

NDs can be divided into the acute and chronic according to the periods of damage. Stroke and spinal cord injury (SCI) are acute NDs that result from temporal damage to the CNS by vascular and physical accidents, respectively [14]; the duration of damage from acute NDs is from seconds to minutes. On the contrary, chronic NDs cause slow, progressive loss of particular or generalized neuronal subtypes, such as Alzheimer's disease (AD), Huntington's disease (HD), Parkinson's disease (PD), and amyotrophic lateral sclerosis (ALS) [15]. Although the loss of neurons in the CNS is the common feature of acute and chronic NDs, there are different mechanisms of neuronal death. Because NDs have their own pathologies, the proper therapeutic genes for each disease should differ by disease type (Table 1) [16-71].

\section{Alzheimer's disease}

The pathologic features of $A D$ include abnormal accumula- tion of extracellular amyloid (A $\beta$ ) peptides, formation of intraneuronal neurofibrillary tangles, extensive synaptic loss, and generalized cellular degeneration [72]. Among the various neuronal populations, the loss of the basal forebrain cholinergic neurons is particularly severe $[73,74]$; the loss of cholinergic neurons in AD correlates with functional severity of dementia, density of amyloid plaques in the brain, and amount of synaptic loss [75]. Therefore, gene therapies for $A D$ have been developed to augment the function of degenerating cholinergic neurons or block neuronal death [76]. Nerve growth factor (NGF) or brain-derived neurotrophic factor (BDNF) gene delivery suppresses the death of the cholinergic neurons and elevates choline acetyltransferase function. Peroxisome proliferator-activated receptor $\gamma$ coactivator $1 \alpha(P G C-1 \alpha)$ and sirtuin 1 (SIRT1) are expected to promote the nonamyloidogenic processing of amyloid precursor protein and preclude the generation of amyloidogenic $A \beta$ peptides $[16,17]$. In contrast, cholesterol 24-hydroxylase prevents brain cholesterol accumulation, a risk factor for $A D$, by converting cholesterol into 24S-hydroxycholesterol.

\section{Parkinson's disease}

Activities of mesencephalic dopaminergic neurons are specifically reduced in PD [18]. Because of its clear pathophysiology, gene therapy for PD is the most advanced in clinical trials (Table 1). To increase dopamine production, genes involved in dopamine neurotransmitter synthesis such as aromatic amino acid decarboxylase and tyrosine hydroxylase have been utilized [77-79]. Glutamic acid decarboxylase is expected to convert a subset of excitatory neurons to gamma-aminobutyric acid-producing inhibitory neurons whose activities are also reduced in PD. Adeno-associated virus (AAV) expressing NGF, glial cell-derived neurotrophic factor (GDNF), BDNF, and neurturin were designed to protect the degenerating nigrostriatum [80-82].

\section{Huntington's disease}

$\mathrm{HD}$ is a hereditary triplet repeat disorder of the CNS in which certain gene sequences are mistakenly repeated [83]. The protein, mutant huntingtin ( $\mathrm{mHtt}$ ), is toxic, and it gradually damages neurons in the brain [84]. $\mathrm{mHtt}$ induces energy dysregulation by repressing transcription of $P G C-1 \alpha$, a regulator of mitochondrial metabolism. $P G C$ - 1 a prevents loss of individual neuronal volumes and supports mitochondrial involvement. Therefore, mitochondria from HD patients show reduced calcium-buffering capacity and increased leakage of calcium into cytoplasm, which in turn causes excitotoxicity 


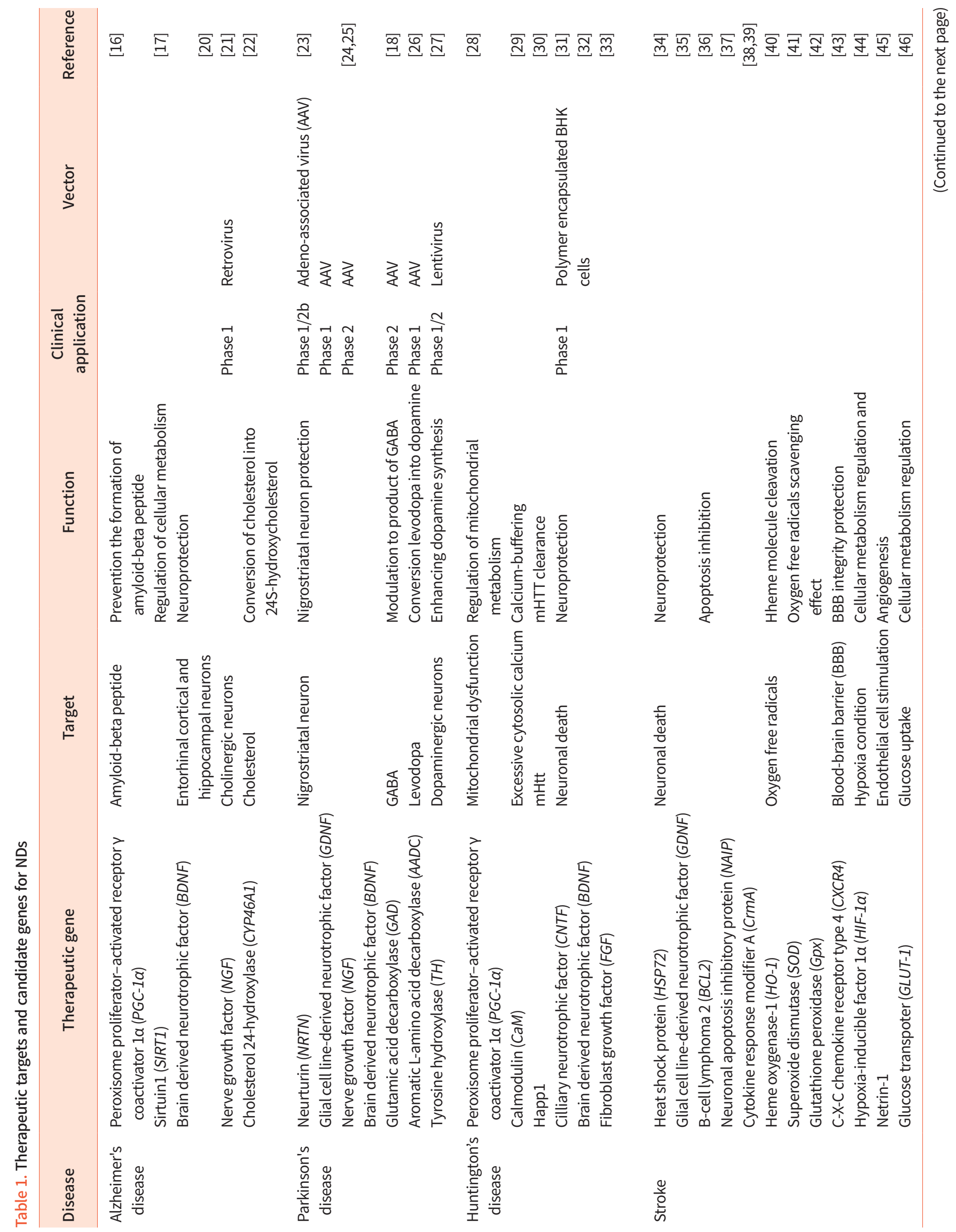


PRECISION AND FUTURE MIEDICINE

Stem cell gene therapy

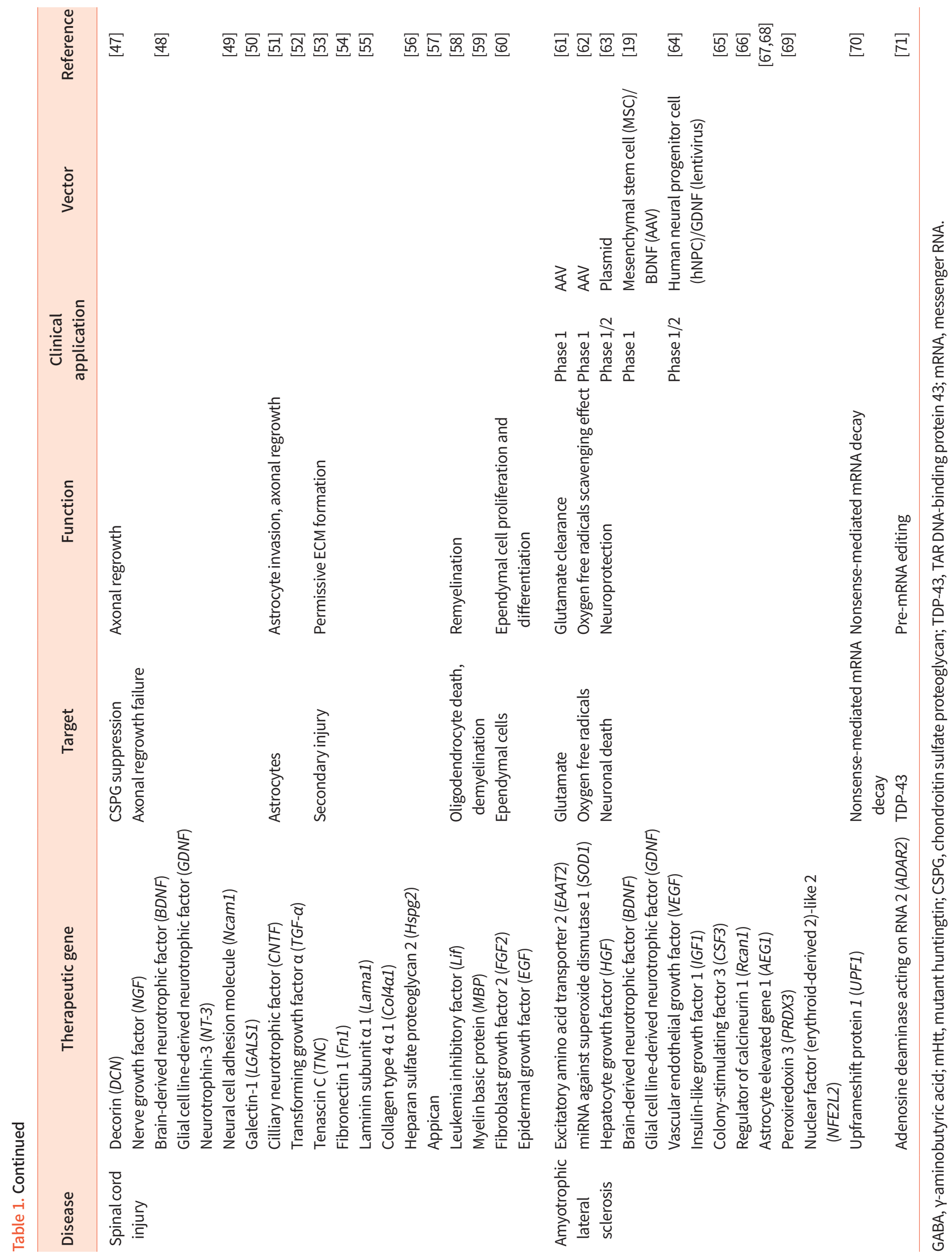


and aberrant calcium signaling. Calmodulin $(\mathrm{CaM})$ is a regulatory protein that binds calcium and activates many enzymes upon calcium binding. Therefore, supplements of $P G C-1 \alpha$ and CaM would protect mitochondria and buffer calcium effects, respectively. Happ1 is a recombinant antibody fragment that recognizes the polyP and P-rich domains of $\mathrm{mHtt}$, and delivery of Happ1 could reduce $\mathrm{mHtt}$ aggregation. Genes of neurotrophic factors such as BDNF, ciliary neurotrophic factor (CNTF), and fibroblast growth factor (FGF) can enhance neuron survival.

\section{Stroke}

Stroke can be divided into ischemic and hemorrhagic. Blockage of blood vessels that supply oxygen and nutrients to the brain results in energy depletion and death of neural cells in the affected areas $[85,86]$. Gene therapy could be useful in treating stroke by stabilizing blood vessels ( $\mathrm{C}-\mathrm{X}-\mathrm{C}$ chemokine receptor type 4 [CXCR4]), stimulating regrowth of blood vessels (hypoxia-inducible factor 1 [HIF-1] and netrin-1), or preventing neuronal death (HSP72, GDNF, B-cell lymphoma 2 [BCL2], neuronal apoptosis inhibitory protein [NAIP], and cytokine response modifier $\mathrm{A}[\mathrm{CrmA}]$ ) (Table 1). Although restoration of blood flow to an ischemic brain is essential to prevent irreversible brain injury, reperfusion may result in further damage by increased inflammation and oxidative stress. The production of toxic oxygen radicals by reperfusion might be reduced by the delivery of genes that enzymatically remove oxygen radical species (heme oxygenase-1 [HO-1], superoxide dismutase $[S O D]$, and glutathione peroxidase $[G p x])$. Meanwhile, a glucose transporter gene (GLUT-1) would promote glucose uptake of neurons and prevent the energy depletion that induces apoptosis.

\section{Spinal cord injury}

$\mathrm{SCl}$ patients experience sudden loss of sensory, motor, and autonomic functions distal to the level of trauma $[87,88]$. The primary mechanism of $\mathrm{SCl}$ is necrosis of damaged neural tissues [89]; however, secondary mechanisms of $\mathrm{SCl}$ including ischemia, inflammation, and delayed apoptosis of neurons follow and worsen the functional losses [90,91]. Because the damaged lesions in $\mathrm{SCl}$ contain various exons that connect neurons, sensory organs, and muscles, reconnection could be a regenerative treatment for $\mathrm{SCl}$. To improve axonal regrowth, many therapeutic genes have been tested, such as decorin (DCN), NGF, GDNF, neurotrophin-3 (NT-3), neural cell adhesion molecule (Ncam1), galectin-1, and CNTF (Table 1). In particular, $D C N$ suppresses inhibitory chondroitin sulfate proteoglycan to promote axonal growth of neurons. Some therapeutic genes can target astrocytes or oligodendrocyte to make favorable environments for recovery. Transforming growth factor $\alpha$ (TGF- $\alpha$ ) increases astrocyte invasion into damaged neural tissues and promotes axonal growth into lesions. Leukemia inhibitory factor (LIF) and myelin basic protein $(M B P)$ are involved in the remyelination of oligodendrocytes that is important for stabilizing exons. Fibroblast growth factor 2 (FGF2) and epidermal growth factor (EGF) induce proliferation and differentiation of ependymal cells. Moreover, there are therapeutic genes that intend to reduce secondary injuries (i.e., fibronectin 1 [Fn1], laminin subunit a 1 [Lama1], collagen type 4 a 1 [Col4a1], heparan sulfate proteoglycan 2 [Hspg2], and appican). Using these therapeutic genes is expected to enhance axonal regrowth, neuroprotection, remyelination, and modulating microenvironments in $\mathrm{SCl}[92,93]$.

\section{Amyotrophic lateral sclerosis}

ALS is a ND that causes relentlessly progressive weakness of the arms, legs, and respiratory muscles [94,95]. Although there are no clear causes of ALS, $3 \%$ of patients have a familial form (FALS) that is phenotypically identical to the sporadic illness. FALS is caused by a mutation in SOD1 that makes excessive toxic oxygen radicals [19]; in addition, there are significant increases in the plasma levels of glutamate in ALS patients [96]. Based on the genotypes and phenotypes, gene therapy for ALS uses microRNA against SOD1 to induce degradation of SOD1 mRNA and a glutamate transporter gene (excitatory amino acid transporter 2 [EAAT2]) that clears excessive glutamates in microenvironments. The potential gene therapy for ALS may involve alteration in the mRNA processing (upframeshift protein 1 [UPF1] and adenosine deaminase acting on RNA 2 [ADAR2]) and inhibition of neuronal cell death (hepatocyte growth factor [HGF], BDNF, GDNF, vascular endothelial growth factor [VEGF], IFG1, colony-stimulating factor 3 [CSF3], regulator of calcineurin 1 [Rcan1], astrocyte elevated gene 1 [AEG-1], peroxiredoxin 3 [PRDX3], and nuclear factor [erythroid-derived 2]-like 2 [NFE2L2]). Especially, there are the clinical trials for ALS which apply stem cells expressing BDNF or GDNF [97].

\section{GENE DELIVERY TECHNIQUES FOR STEM CELL GENE THERAPY}

There are two major therapeutic gene-delivery methods in gene therapy. In vivo delivery entails directly injecting thera- 


\section{Gene modified cell therapeutics}

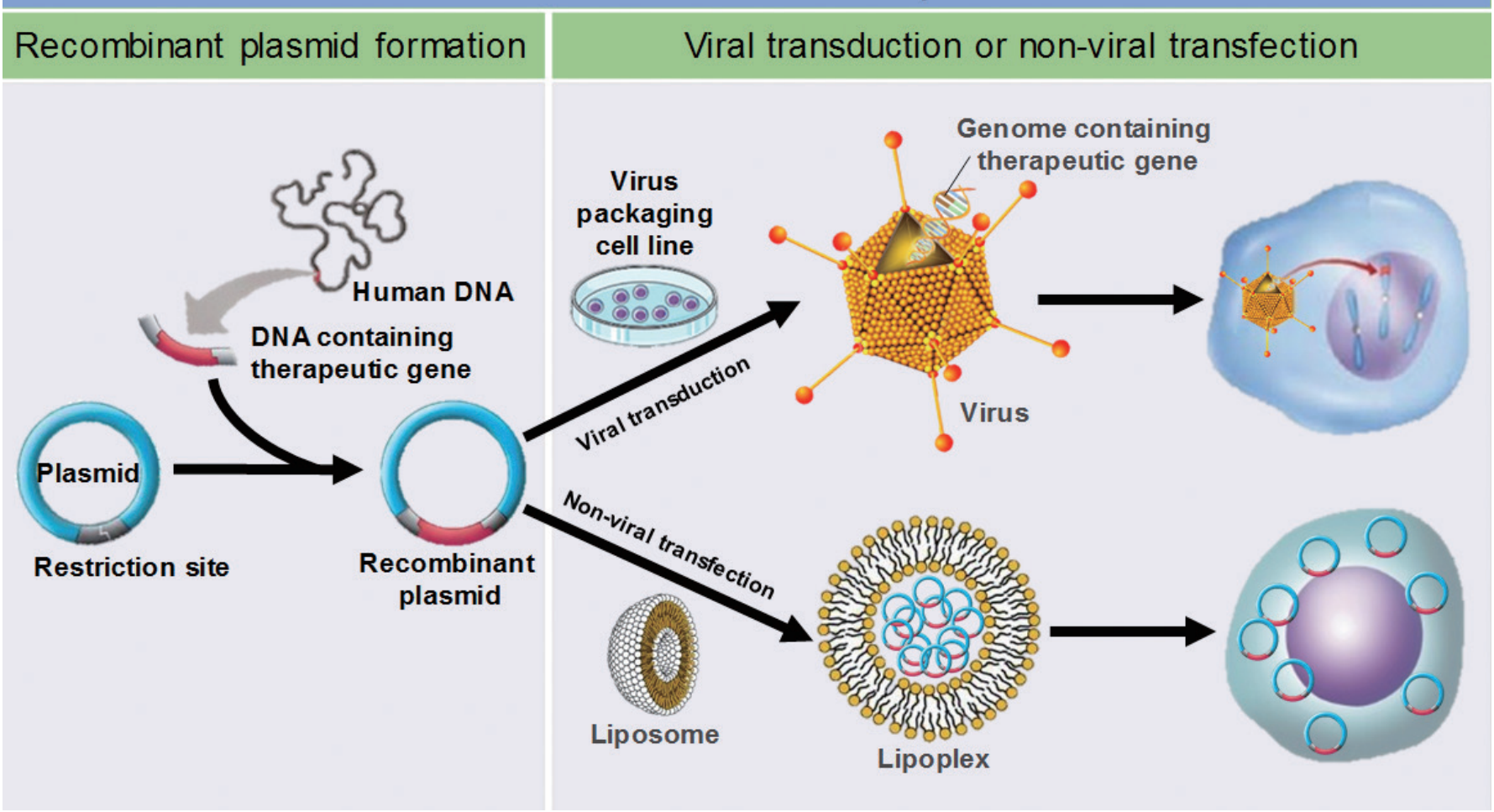

Fig. 1. Gene delivery methods for stem cell gene therapy.

Table 2. Advantages and disadvantages of viral therapeutic gene delivery methods

\begin{tabular}{|c|c|c|}
\hline Vector & Advantage & Disadvantage \\
\hline \multirow[t]{3}{*}{ Adenovirus } & High transduction efficiency & Strong immunogenicity \\
\hline & Transduction is possible into dividing and non-dividing cells & Transient expression of inserted gene \\
\hline & Easy to produce & \\
\hline \multirow[t]{3}{*}{ Retrovirus } & Permanent stable expression of inserted gene & Low transduction efficiency \\
\hline & Low immunogenicity & Transduction is possible into dividing cells only \\
\hline & Abundant experiences in clinical trials & Possible insertional mutagenesis \\
\hline \multirow[t]{4}{*}{ Lentivirus } & Permanent stable expression of inserted gene & Limited size of inserted gene (up to $8 \mathrm{~kb}$ ) \\
\hline & Transduction is possible into dividing and non-dividing cells & \\
\hline & Transduction is possible into various types of cells & \\
\hline & Low immunogenicity & \\
\hline \multirow[t]{4}{*}{ Adeno-associated virus } & Permanent stable expression of inserted gene & Limited size of inserted gene (up to $4.5 \mathrm{~kb}$ ) \\
\hline & High transduction efficiency & Difficulties in production \\
\hline & Transduction is possible into various types of cells & \\
\hline & Low immunogenicity & \\
\hline \multirow[t]{3}{*}{ Herpes virus } & High transduction efficiency into neuron & Transient expression of inserted gene \\
\hline & Little limitation in the size of inserted gene (up to $152 \mathrm{~kb}$ ) & Difficulties in production \\
\hline & Carrying multiple genes & \\
\hline
\end{tabular}


PRECISION AND FUTURE MEDICINE

Ji-Yoon Hwang, et al.

Table 3. Advantages and disadvantages of non-viral therapeutic gene delivery methods

\begin{tabular}{lll}
\hline Vector & \multicolumn{1}{c}{ Advantage } & \multicolumn{1}{c}{ Disadvantage } \\
\hline Naked DNA/Plasmid & Simple and cost-effective process of production and storage & Transient expression of gene \\
& Low immunogenicity & Low transfection efficiency \\
& High safety & \\
Liposome & Higher transfection efficiency & Transient expression of gene \\
& Simple process of production and storage & Rare experiences in clinical trials \\
Electroporation & Low immunogenicity & \\
Hene gun & High safety & Low cellular viability after electrical shock \\
& Protein delivery is also possible & Damage of cells or tissues \\
& Good efficiency of ex vivo gene transfer & Limited applications \\
\hline
\end{tabular}

peutic genes into the body using viral or nonviral vehicles [98]. Ex vivo delivery loads cells with therapeutic genes, and then the cells that express the genes are injected into the body [99]. For stem cell gene therapy, therapeutic genes are transferred to stem cells ex vivo, and this results in transient or permanent expression of therapeutic genes within stem cells according to gene transfer methods (Fig. 1).

Gene transfer methods use viral or non-viral vectors that all have their own advantages and disadvantages (Tables 2, 3). In clinical trials, viral delivery methods have been utilized including adenovirus (AV), retrovirus (RV), lentivirus (LV), AAV, and herpes virus (HV) $[100,101]$. Viral delivery methods usually show high efficiency of therapeutic genes' transduction and expression, although these can be affected by the genes' sizes and vectors. AV is technically easy to produce and can carry relatively large genes, and it infects both dividing and nondividing cells. However, it has relatively high immunogenicity and the expression of therapeutic genes is essentially transient. However, RV has merits in the long-term stable expression of therapeutic genes if the genes integrate into the host genome; RV infects only dividing cells. The challenge is that integration of therapeutic genes into the host genome carries the risk of insertional mutagenesis. Due to the advantages of $\mathrm{RV}$, it is the most used viral vector in clinical trials of gene therapy.

LV is a viral vector modified from human immunodeficiency virus (HIV) to have no disease-inducing activities and low immunogenicity. LV infects nondividing and dividing cells and delivers therapeutic genes to broader types of cells than RV. As with RV, LV shows long-term stable expression of therapeutic genes based on the genes' integration into the host ge- nome, and it can possibly result in insertional mutagenesis. AAV infects both dividing and nondividing cells and has low immunogenicity. Long-time expression of inserted genes can be achieved with AAV. Although insertional mutagenesis is possible, site-specific integration of therapeutic genes into the host genome by AAV reduces the possibility dramatically. Limitation in the sizes of therapeutic genes and technical difficulties in the production are weak points of AAV.

$\mathrm{HV}$ can efficiently infect nondividing neurons in the CNS and carry multiple therapeutic genes at the same time. However, production of $\mathrm{HV}$ is relatively complex, and only transient expression of therapeutic genes is possible by HV. In many cases, viral delivery methods have safety concerns due to the permanent insertion of therapeutic genes into the host genome, which might provoke unwanted genetic mutations and tumorigenicity [102]. This risk is more important in stem cell gene therapy given that stem cells have been reported as possible sources of cancer development.

Nonviral delivery refers to plasmid-based delivery of therapeutic genes using chemical or physical stimulation [103]. The basic material of non-viral delivery is naked plasmid DNA (pDNA) containing therapeutic genes. The simplest application method is direct administration of naked pDNA without any chemical or physical assistances [104]. Various types of injection routes have been explored for naked pDNA including intravascular/intramuscular injection and inhalation [105]. However, the most disadvantage of it is low transfection efficiency. To improve the efficiency, mechanical or physical methods (i.e., electroporation and gene gun) have been applied to naked pDNA. Electroporation is brief electric pulses which induce the formation of transient pores in the mem- 
brane of target cells [106]. Such pores have little impact on the survival of cells but make functional ways through which pDNA can cross hydrophobic lipid bilayer [107]. The transfection efficiency of electroporation is reported as about 100 - to 1,000 -fold higher than that of direct administration of naked pDNA alone [108].

Gene gun is another physical approach to enhance the delivery of pDNA. Gene gun uses particle bombardment to shoot DNA-coated microscopic pellets through the cell membrane [107]. Recently a significant improvement in tissue penetration had been achieved using a newly designed gene gun, which allows longer gene expression of pDNA in subcutaneous tissues, such as muscle or tumor [109]. Liposome is a vesicular structure that is formed by the interaction and accumulation of lipids, in which pDNA is included [110]. Liposome is not a rigid formation but fluid entity that is versatile supramolecular assemblies. Based on its dynamic properties, it can fuse with the cell membrane to release pDNA into the cytoplasm. Moreover, liposome is relatively easy to manipulate, which make liposome used widely for the delivery of genes as well as drugs [111].

Compared with the viral methods, plasmid production is simpler, and there is little limitation of the size of the inserted gene. However, the efficiency of gene transfection and expression are lower than with the viral methods. Advantages and disadvantages of each nonviral method are summarized in Table 3.

\section{CONCLUSION}

Stem cell therapies have their own limitations in that stem cells by themselves cannot reverse the processes or correct the causes of NDs even though they regenerate damaged neural tissues. In contrast, gene therapy can correct genetic defects or express beneficial therapeutic genes that modify specific disease processes. Whereas many candidate therapeutic genes for NDs have been identified, their clinical uses as gene therapies are limited due to ineffective delivery and safety concerns. Combining stem cells and therapeutic genes might solve those issues in the gene therapy. Moreover, stem cells could regenerate neural tissue that cannot be repaired spontaneously. Although the methods of delivering therapeutic genes into stem cells is another technical issue, stem cell gene therapy might provide novel options for treating NDs that have more potent effects.

\section{CONFLICTS OF INTEREST}

No potential conflict of interest relevant to this article was reported.

\section{ACKNOWLEDGMENTS}

This research was supported by grants from Ministry of Food and Drug Safety in 2018 (18172MFDS182) and National Research Foundation (NRF-2016R1A5A2945889).

\section{REFERENCES}

1. Palop JJ, Chin J, Mucke L. A network dysfunction perspective on neurodegenerative diseases. Nature 2006; 443:768-73.

2. Fawcett JW. Astrocytic and neuronal factors affecting axon regeneration in the damaged central nervous system. Cell Tissue Res 1997;290:371-7.

3. Gao HM, Hong JS. Why neurodegenerative diseases are progressive: uncontrolled inflammation drives disease progression. Trends Immunol 2008;29:357-65.

4. Yoon DS, Choi Y, Jang Y, Lee M, Choi WJ, Kim SH, et al. SIRT1 directly regulates SOX2 to maintain self-renewal and multipotency in bone marrow-derived mesenchymal stem cells. Stem Cells 2014;32:3219-31.

5. Oron A, Oron U. Low-level laser therapy to the bone marrow ameliorates neurodegenerative disease progression in a mouse model of Alzheimer's disease: a minireview. Photomed Laser Surg 2016;34:627-30.

6. Zigmond MJ. Do compensatory processes underlie the preclinical phase of neurodegenerative disease? Insights from an animal model of parkinsonism. Neurobiol Dis 1997;4:247-53.

7. Joyce N, Annett G, Wirthlin L, Olson S, Bauer G, Nolta JA. Mesenchymal stem cells for the treatment of neurodegenerative disease. Regen Med 2010;5:933-46.

8. Trounson A, Thakar RG, Lomax G, Gibbons D. Clinical trials for stem cell therapies. BMC Med 2011;9:52.

9. Wurmser AE, Palmer TD, Gage FH. Neuroscience. Cellular interactions in the stem cell niche. Science 2004;304: 1253-5.

10. St George JA. Gene therapy progress and prospects: adenoviral vectors. Gene Ther 2003;10:1135-41.

11. Brunetti-Pierri N, Ng P. Progress and prospects: gene therapy for genetic diseases with helper-dependent adenoviral vectors. Gene Ther 2008;15:553-60. 
12. Dachs GU, Dougherty GJ, Stratford IJ, Chaplin DJ. Targeting gene therapy to cancer: a review. Oncol Res 1997; 9:313-25.

13. Biffi A, Montini E, Lorioli L, Cesani M, Fumagalli F, Plati T, et al. Lentiviral hematopoietic stem cell gene therapy benefits metachromatic leukodystrophy. Science 2013; 341:1233158.

14. Popovich PG, Wei P, Stokes BT. Cellular inflammatory response after spinal cord injury in Sprague-Dawley and Lewis rats. J Comp Neurol 1997;377:443-64.

15. O'Connor DM, Boulis NM. Gene therapy for neurodegenerative diseases. Trends Mol Med 2015;21:504-12.

16. Qin W, Haroutunian V, Katsel P, Cardozo CP, Ho L, Buxbaum JD, et al. PGC-1alpha expression decreases in the Alzheimer disease brain as a function of dementia. Arch Neurol 2009;66:352-61.

17. Qin W, Yang T, Ho L, Zhao Z, Wang J, Chen L, et al. Neuronal SIRT1 activation as a novel mechanism underlying the prevention of Alzheimer disease amyloid neuropathology by calorie restriction. J Biol Chem 2006;281:21745-54.

18. Kaplitt MG, Feigin A, Tang C, Fitzsimons HL, Mattis P, Lawlor PA, et al. Safety and tolerability of gene therapy with an adeno-associated virus (AAV) borne GAD gene for Parkinson's disease: an open label, phase I trial. Lancet 2007;369:2097-105.

19. Williams KL, McCann EP, Fifita JA, Zhang K, Duncan EL, Leo PJ, et al. Novel TBK1 truncating mutation in a familial amyotrophic lateral sclerosis patient of Chinese origin. Neurobiol Aging 2015;36:3334.e1-e5.

20. Blurton-Jones M, Kitazawa M, Martinez-Coria H, Castello NA, Muller FJ, Loring JF, et al. Neural stem cells improve cognition via BDNF in a transgenic model of Alzheimer disease. Proc Natl Acad Sci U S A 2009;106:13594-9.

21. Cuello AC, Bruno MA, Allard S, Leon W, Iulita MF. Cholinergic involvement in Alzheimer's disease. A link with NGF maturation and degradation. J Mol Neurosci 2010; 40:230-5.

22. Djelti F, Braudeau J, Hudry E, Dhenain M, Varin J, Bieche I, et al. CYP46A1 inhibition, brain cholesterol accumulation and neurodegeneration pave the way for Alzheimer's disease. Brain 2015;138(Pt 8):2383-98.

23. Rosenblad C, Kirik D, Devaux B, Moffat B, Phillips HS, Bjorklund A. Protection and regeneration of nigral dopaminergic neurons by neurturin or GDNF in a partial lesion model of Parkinson's disease after administration into the striatum or the lateral ventricle. Eur J Neurosci 1999;11:1554-66.
24. Mogi M, Togari A, Kondo T, Mizuno Y, Komure O, Kuno S, et al. Brain-derived growth factor and nerve growth factor concentrations are decreased in the substantia nigra in Parkinson's disease. Neurosci Lett 1999;270:45-8.

25. Lorigados Pedre L, Pavon Fuentes N, Alvarez Gonzalez L, McRae A, Serrano Sanchez T, Blanco Lescano L, et al. Nerve growth factor levels in Parkinson disease and experimental parkinsonian rats. Brain Res 2002;952:122-7.

26. Christine CW, Starr PA, Larson PS, Eberling JL, Jagust WJ, Hawkins RA, et al. Safety and tolerability of putaminal AADC gene therapy for Parkinson disease. Neurology 2009;73:1662-9.

27. Palfi S, Gurruchaga JM, Ralph GS, Lepetit H, Lavisse S, Buttery PC, et al. Long-term safety and tolerability of ProSavin, a lentiviral vector-based gene therapy for Parkinson's disease: a dose escalation, open-label, phase 1/2 trial. Lancet 2014;383:1138-46.

28. Chaturvedi RK, Calingasan NY, Yang L, Hennessey T, Johri A, Beal MF. Impairment of PGC-1alpha expression, neuropathology and hepatic steatosis in a transgenic mouse model of Huntington's disease following chronic energy deprivation. Hum Mol Genet 2010;19:3190-205.

29. Bao J, Sharp AH, Wagster MV, Becher M, Schilling G, Ross $C A$, et al. Expansion of polyglutamine repeat in huntingtin leads to abnormal protein interactions involving calmodulin. Proc Natl Acad Sci U S A 1996;93:5037-42.

30. Southwell AL, Ko J, Patterson PH. Intrabody gene therapy ameliorates motor, cognitive, and neuropathological symptoms in multiple mouse models of Huntington's disease. J Neurosci 2009;29:13589-602.

31. de Almeida LP, Zala D, Aebischer P, Deglon N. Neuroprotective effect of a CNTF-expressing lentiviral vector in the quinolinic acid rat model of Huntington's disease. Neurobiol Dis 2001;8:433-46.

32. Bemelmans AP, Horellou P, Pradier L, Brunet I, Colin P, Mallet J. Brain-derived neurotrophic factor-mediated protection of striatal neurons in an excitotoxic rat model of Huntington's disease, as demonstrated by adenoviral gene transfer. Hum Gene Ther 1999;10:2987-97.

33. Haque NS, Isacson O. Neurotrophic factors NGF and FGF-2 alter levels of huntingtin (IT15) in striatal neuronal cell cultures. Cell Transplant 2000;9:623-7.

34. Yenari MA, Fink SL, Sun GH, Chang LK, Patel MK, Kunis DM, et al. Gene therapy with HSP72 is neuroprotective in rat models of stroke and epilepsy. Ann Neurol 1998;44:584-91.

35. Kobayashi T, Ahlenius H, Thored P, Kobayashi R, Kokaia $Z$, Lindvall $\mathrm{O}$. Intracerebral infusion of glial cell line-de- 
rived neurotrophic factor promotes striatal neurogenesis after stroke in adult rats. Stroke 2006;37:2361-7.

36. Zhao H, Yenari MA, Cheng D, Sapolsky RM, Steinberg GK. $\mathrm{Bcl}-2$ overexpression protects against neuron loss within the ischemic margin following experimental stroke and inhibits cytochrome $\mathrm{c}$ translocation and caspase-3 activity. J Neurochem 2003;85:1026-36.

37. Xu DG, Crocker SJ, Doucet JP, St-Jean M, Tamai K, Hakim AM, et al. Elevation of neuronal expression of NAIP reduces ischemic damage in the rat hippocampus. Nat Med 1997;3:997-1004.

38. Ekert PG, Silke J, Vaux DL. Caspase inhibitors. Cell Death Differ 1999;6:1081-6.

39. Dammann O, Leviton A. Brain damage in preterm newborns: biological response modification as a strategy to reduce disabilities. J Pediatr 2000;136:433-8.

40. Nimura T, Weinstein PR, Massa SM, Panter S, Sharp FR. Heme oxygenase-1 (HO-1) protein induction in rat brain following focal ischemia. Brain Res Mol Brain Res 1996; 37:201-8.

41. Spranger M, Krempien S, Schwab S, Donneberg S, Hacke W. Superoxide dismutase activity in serum of patients with acute cerebral ischemic injury. Correlation with clinical course and infarct size. Stroke 1997;28:2425-8.

42. Hoehn B, Yenari MA, Sapolsky RM, Steinberg GK. Glutathione peroxidase overexpression inhibits cytochrome $C$ release and proapoptotic mediators to protect neurons from experimental stroke. Stroke 2003;34:2489-94.

43. Huang J, Li Y, Tang Y, Tang G, Yang GY, Wang Y. CXCR4 antagonist AMD3100 protects blood-brain barrier integrity and reduces inflammatory response after focal ischemia in mice. Stroke 2013;44:190-7.

44. Cunningham LA, Candelario K, Li L. Roles for HIF-1alpha in neural stem cell function and the regenerative response to stroke. Behav Brain Res 2012;227:410-7.

45. Lu H, Wang Y, He X, Yuan F, Lin X, Xie B, et al. Netrin-1 hyperexpression in mouse brain promotes angiogenesis and long-term neurological recovery after transient focal ischemia. Stroke 2012;43:838-43.

46. Lawrence MS, Sun GH, Kunis DM, Saydam TC, Dash R, Ho DY, et al. Overexpression of the glucose transporter gene with a herpes simplex viral vector protects striatal neurons against stroke. J Cereb Blood Flow Metab 1996; 16:181-5.

47. Davies JE, Tang X, Denning JW, Archibald SJ, Davies SJ. Decorin suppresses neurocan, brevican, phosphacan and NG2 expression and promotes axon growth across adult rat spinal cord injuries. Eur J Neurosci 2004;19:1226-42.

48. Tokumine J, Kakinohana O, Cizkova D, Smith DW, Marsala M. Changes in spinal GDNF, BDNF, and NT-3 expression after transient spinal cord ischemia in the rat. J Neurosci Res 2003;74:552-61.

49. Papastefanaki F, Chen J, Lavdas AA, Thomaidou D, Schachner M, Matsas R. Grafts of Schwann cells engineered to express PSA-NCAM promote functional recovery after spinal cord injury. Brain 2007;130(Pt 8):2159-74.

50. Yamane J, Nakamura M, Iwanami A, Sakaguchi M, Katoh H, Yamada M, et al. Transplantation of galectin-1-expressing human neural stem cells into the injured spinal cord of adult common marmosets. J Neurosci Res 2010;88:1394405.

51. Albrecht PJ, Dahl JP, Stoltzfus OK, Levenson R, Levison SW. Ciliary neurotrophic factor activates spinal cord astrocytes, stimulating their production and release of fibroblast growth factor-2, to increase motor neuron survival. Exp Neurol 2002;173:46-62.

52. White RE, Yin FQ, Jakeman LB. TGF-alpha increases astrocyte invasion and promotes axonal growth into the lesion following spinal cord injury in mice. Exp Neurol 2008;214:10-24.

53. Chen J, Joon Lee H, Jakovcevski I, Shah R, Bhagat N, Loers $\mathrm{G}$, et al. The extracellular matrix glycoprotein tenascin- $\mathrm{C}$ is beneficial for spinal cord regeneration. Mol Ther 2010;18:1769-77.

54. King VR, Alovskaya A, Wei DY, Brown RA, Priestley JV. The use of injectable forms of fibrin and fibronectin to support axonal ingrowth after spinal cord injury. Biomaterials 2010;31:4447-56.

55. Cheng H, Huang YC, Chang PT, Huang YY. Laminin-incorporated nerve conduits made by plasma treatment for repairing spinal cord injury. Biochem Biophys Res Commun 2007;357:938-44.

56. Lander AD, Fujii DK, Gospodarowicz D, Reichardt LF. Characterization of a factor that promotes neurite outgrowth: evidence linking activity to a heparan sulfate proteoglycan. J Cell Biol 1982;94:574-85.

57. Wu A, Pangalos MN, Efthimiopoulos S, Shioi J, Robakis NK. Appican expression induces morphological changes in $\mathrm{C} 6$ glioma cells and promotes adhesion of neural cells to the extracellular matrix. J Neurosci 1997;17:4987-93.

58. Kerr BJ, Patterson PH. Leukemia inhibitory factor promotes oligodendrocyte survival after spinal cord injury. Glia 2005;51:73-9.

59. Jones TB, Ankeny DP, Guan Z, McGaughy V, Fisher LC, 
Basso DM, et al. Passive or active immunization with myelin basic protein impairs neurological function and exacerbates neuropathology after spinal cord injury in rats. J Neurosci 2004;24:3752-61.

60. Jimenez Hamann MC, Tator CH, Shoichet MS. Injectable intrathecal delivery system for localized administration of EGF and FGF-2 to the injured rat spinal cord. Exp Neurol 2005;194:106-19.

61. Meyer T, Fromm A, Munch C, Schwalenstocker B, Fray $A E$, Ince PG, et al. The RNA of the glutamate transporter EAAT2 is variably spliced in amyotrophic lateral sclerosis and normal individuals. J Neurol Sci 1999;170:45-50.

62. Ripps ME, Huntley GW, Hof PR, Morrison JH, Gordon JW. Transgenic mice expressing an altered murine superoxide dismutase gene provide an animal model of amyotrophic lateral sclerosis. Proc Natl Acad Sci U S A 1995; 92:689-93.

63. Kato S, Funakoshi H, Nakamura T, Kato M, Nakano I, Hirano $A$, et al. Expression of hepatocyte growth factor and c-Met in the anterior horn cells of the spinal cord in the patients with amyotrophic lateral sclerosis (ALS): immunohistochemical studies on sporadic ALS and familial ALS with superoxide dismutase 1 gene mutation. Acta Neuropathol 2003;106:112-20.

64. Akiyama H, Nishimura T, Kondo H, Ikeda K, Hayashi Y, McGeer PL. Expression of the receptor for macrophage colony stimulating factor by brain microglia and its upregulation in brains of patients with Alzheimer's disease and amyotrophic lateral sclerosis. Brain Res 1994;639: 171-4.

65. Ferri A, Nencini M, Battistini S, Giannini F, Siciliano G, Casali $\mathrm{C}$, et al. Activity of protein phosphatase calcineurin is decreased in sporadic and familial amyotrophic lateral sclerosispatients. J Neurochem 2004;90: 1237-42.

66. Yin X, Ren M, Jiang H, Cui S, Wang S, Jiang H, et al. Downregulated AEG-1 together with inhibited PI3K/Akt pathway is associated with reduced viability of motor neurons in an ALS model. Mol Cell Neurosci 2015;68: 303-13.

67. Rabilloud T, Heller M, Rigobello MP, Bindoli A, Aebersold $\mathrm{R}$, Lunardi J. The mitochondrial antioxidant defence system and its response to oxidative stress. Proteomics 2001;1:1105-10.

68. Nanou A, Higginbottom A, Valori CF, Wyles M, Ning K, Shaw $P$, et al. Viral delivery of antioxidant genes as a therapeutic strategy in experimental models of amyo- trophic lateral sclerosis. Mol Ther 2013;21:1486-96.

69. Vargas MR, Johnson DA, Sirkis DW, Messing A, Johnson JA. Nrf2 activation in astrocytes protects against neurodegeneration in mouse models of familial amyotrophic lateral sclerosis. J Neurosci 2008;28:13574-81.

70. Jackson KL, Dayton RD, Orchard EA, Ju S, Ringe D, Petsko GA, et al. Preservation of forelimb function by UPF1 gene therapy in a rat model of TDP-43-induced motor paralysis. Gene Ther 2015;22:20-8.

71. Yamashita T, Chai HL, Teramoto S, Tsuji S, Shimazaki K, Muramatsu S, et al. Rescue of amyotrophic lateral sclerosis phenotype in a mouse model by intravenous AAV9ADAR2 delivery to motor neurons. EMBO Mol Med 2013; 5:1710-9.

72. Hardy J, Selkoe DJ. The amyloid hypothesis of Alzheimer's disease: progress and problems on the road to therapeutics. Science 2002;297:353-6.

73. Whitehouse PJ, Price DL, Struble RG, Clark AW, Coyle JT, Delon MR. Alzheimer's disease and senile dementia: loss of neurons in the basal forebrain. Science 1982;215: 1237-9.

74. Fonnum F. A rapid radiochemical method for the determination of choline acetyltransferase. J Neurochem 1975; 24:407-9.

75. Lehericy S, Hirsch EC, Cervera-Pierot P, Hersh LB, Bakchine $S$, Piette $F$, et al. Heterogeneity and selectivity of the degeneration of cholinergic neurons in the basal forebrain of patients with Alzheimer's disease. J Comp Neurol 1993;330:15-31.

76. Tuszynski MH, Blesch A. Nerve growth factor: from animal models of cholinergic neuronal degeneration to gene therapy in Alzheimer's disease. Prog Brain Res 2004;146:441-9.

77. Horellou P, Vigne E, Castel MN, Barneoud P, Colin P, Perricaudet $\mathrm{M}$, et al. Direct intracerebral gene transfer of an adenoviral vector expressing tyrosine hydroxylase in a rat model of Parkinson's disease. Neuroreport 1994;6:4953.

78. Haavik J, Toska K. Tyrosine hydroxylase and Parkinson's disease. Mol Neurobiol 1998;16:285-309.

79. Sun M, Zhang GR, Kong L, Holmes C, Wang X, Zhang W, et al. Correction of a rat model of Parkinson's disease by coexpression of tyrosine hydroxylase and aromatic amino acid decarboxylase from a helper virus-free herpes simplex virus type 1 vector. Hum Gene Ther 2003;14:415-24.

80. Klein RL, Lewis MH, Muzyczka N, Meyer EM. Prevention of 6-hydroxydopamine-induced rotational behavior by BDNF somatic gene transfer. Brain Res 1999;847:314-20. 


\section{PRECISION AND FUTURE MIEDICINE}

Stem cell gene therapy

81. Bjorklund A, Kirik D, Rosenblad C, Georgievska B, Lundberg C, Mandel RJ. Towards a neuroprotective gene therapy for Parkinson's disease: use of adenovirus, AAV and lentivirus vectors for gene transfer of GDNF to the nigrostriatal system in the rat Parkinson model. Brain Res 2000;886:82-98.

82. Gasmi M, Brandon EP, Herzog CD, Wilson A, Bishop KM, Hofer EK, et al. AAV2-mediated delivery of human neurturin to the rat nigrostriatal system: long-term efficacy and tolerability of CERE-120 for Parkinson's disease. Neurobiol Dis 2007;27:67-76.

83. The Huntington's Disease Collaborative Research Group. A novel gene containing a trinucleotide repeat that is expanded and unstable on Huntington's disease chromosomes. Cell 1993;72:971-83.

84. Wellington CL, Ellerby LM, Gutekunst CA, Rogers D, Warby $\mathrm{S}$, Graham RK, et al. Caspase cleavage of mutant huntingtin precedes neurodegeneration in Huntington's disease. J Neurosci 2002;22:7862-72.

85. Qureshi Al, Siddiqui AM, Suri MF, Kim SH, Ali Z, Yahia AM, et al. Aggressive mechanical clot disruption and lowdose intra-arterial third-generation thrombolytic agent for ischemic stroke: a prospective study. Neurosurgery 2002;51:1319-27.

86. Yoon W, Park MS, Cho KH. Low-dose intra-arterial urokinase and aggressive mechanical clot disruption for acute ischemic stroke after failure of intravenous thrombolysis. AJNR Am J Neuroradiol 2010;31:161-4.

87. Sabour S. The neurogenic bowel dysfunction score in patients with spinal cord injury: methodological issues in reliability and validity. Spinal Cord 2018;56:295-6.

88. Valles M, Vidal J, Clave P, Mearin F. Bowel dysfunction in patients with motor complete spinal cord injury: clinical, neurological, and pathophysiological associations. Am J Gastroenterol 2006;101:2290-9.

89. Hackney DB, Asato R, Joseph PM, Carvlin MJ, McGrath JT, Grossman RI, et al. Hemorrhage and edema in acute spinal cord compression: demonstration by MR imaging. Radiology 1986;161:387-90.

90. Tator $\mathrm{CH}$, Fehlings MG. Review of the secondary injury theory of acute spinal cord trauma with emphasis on vascular mechanisms. J Neurosurg 1991;75:15-26.

91. Young W. Secondary injury mechanisms in acute spinal cord injury. J Emerg Med 1993;11 Suppl 1:13-22.

92. Jones LL, Oudega M, Bunge MB, Tuszynski MH. Neurotrophic factors, cellular bridges and gene therapy for spinal cord injury. J Physiol 2001;533(Pt 1):83-9.
93. Martinez-Galvez G, Zambrano JM, Diaz Soto JC, Zhan WZ, Gransee HM, Sieck GC, et al. TrkB gene therapy by adeno-associated virus enhances recovery after cervical spinal cord injury. Exp Neurol 2016;276:31-40.

94. Johnson JO, Pioro EP, Boehringer A, Chia R, Feit H, Renton $\mathrm{AE}$, et al. Mutations in the Matrin 3 gene cause familial amyotrophic lateral sclerosis. Nat Neurosci 2014;17: 664-6.

95. Baxter S, Reed H, Clarke Z, Judge S, Heron N, McCarthy A, et al. Evaluating a novel cervical orthosis, the Sheffield Support Snood, in patients with amyotrophic lateral sclerosis/motor neuron disease with neck weakness. Amyotroph Lateral Scler Frontotemporal Degener 2016; 17:436-42.

96. Meininger V, Genge A, van den Berg LH, Robberecht W, Ludolph A, Chio A, et al. Safety and efficacy of ozanezumab in patients with amyotrophic lateral sclerosis: a randomised, double-blind, placebo-controlled, phase 2 trial. Lancet Neurol 2017;16:208-16.

97. Nicaise C, Mitrecic D, Pochet R. Brain and spinal cord affected by amyotrophic lateral sclerosis induce differential growth factors expression in rat mesenchymal and neural stem cells. Neuropathol Appl Neurobiol 2011;37: 179-88.

98. Kaufmann KB, Buning H, Galy A, Schambach A, Grez M. Gene therapy on the move. EMBO Mol Med 2013;5:164261.

99. Naldini L. Ex vivo gene transfer and correction for cellbased therapies. Nat Rev Genet 2011;12:301-15.

100. Romano G, Pacilio C, Giordano A. Gene transfer technology in therapy: current applications and future goals. Stem Cells 1999;17:191-202.

101. Kootstra NA, Verma IM. Gene therapy with viral vectors. Annu Rev Pharmacol Toxicol 2003;43:413-39.

102. Walther W, Stein U. Viral vectors for gene transfer: a review of their use in the treatment of human diseases. Drugs 2000;60:249-71.

103. Rip J, Nierman MC, Sierts JA, Petersen W, Van den Oever K, Van Raalte D, et al. Gene therapy for lipoprotein lipase deficiency: working toward clinical application. Hum Gene Ther 2005;16:1276-86.

104. Ramamoorth M, Narvekar A. Non viral vectors in gene therapy: an overview. J Clin Diagn Res 2015;9:GE01-6.

105. Park HJ, Yang F, Cho SW. Nonviral delivery of genetic medicine for therapeutic angiogenesis. Adv Drug Deliv Rev 2012;64:40-52.

106. Neumann E, Kakorin S, Toensing K. Fundamentals of 
electroporative delivery of drugs and genes. Bioelectrochem Bioenerg 1999;48:3-16.

107. Nishikawa M, Huang L. Nonviral vectors in the new millennium: delivery barriers in gene transfer. Hum Gene Ther 2001;12:861-70.

108. Young JL, Dean DA. Electroporation-mediated gene delivery. Adv Genet 2015;89:49-88.

109. Dileo J, Miller TE Jr, Chesnoy S, Huang L. Gene transfer to subdermal tissues via a new gene gun design. Hum
Gene Ther 2003;14:79-87.

110. Koltover I, Salditt T, Radler JO, Safinya CR. An inverted hexagonal phase of cationic liposome-DNA complexes related to DNA release and delivery. Science 1998;281: 78-81.

111. Tomori Y, lijima N, Hinuma S, Ishii H, Takumi K, Takai S, et al. Morphological analysis of trafficking and processing of anionic and cationic liposomes in cultured cells. Acta Histochem Cytochem 2018;51:81-92. 